\title{
OLHANDO PELA JANELA: A PAISAGEM URBANA EQUILIBRADA COMO INDICADOR DE QUALIDADE DE VIDA
}

\section{Rodrigo Henrique Branquinho Barboza TOZZI ${ }^{1}$}

ISSUE DOI: $10.21207 / 1983.4225 .504$

\section{Resumo}

A política urbana tem por objetivo garantir o direito a cidades sustentáveis e, por conseguinte, da paisagem urbana ordenada e equilibrada, garantia de qualidade de vida, corolário da dignidade humana, valor insculpido no texto constitucional. Esse trabalho tem como objetivo o estudo da paisagem urbana como bem jurídico, ou seja, merecedora de proteção legal. Visa também associar a paisagem urbana equilibrada ao conceito de qualidade de vida, ideal buscado para todos os habitantes das cidades, verdadeiro direito fundamental.

Palavras-chave: Paisagem urbana. Bem jurídico. Qualidade de vida. Dignidade humana. Direito fundamental.

\begin{abstract}
Urban policy aims to guarantee the right to sustainable cities and, consequently, the orderly and balanced urban landscape, guaranteeing quality of life, corollary of human dignity, an insculated value in the constitutional text. This work aims to study the urban paisa-gem as a legal good, that is, deserving of legal protection. It also aims to associate the balanced urban Paisa-gem with the concept of quality of life, ideal sought for all the inhabitants of the cities, true fundamental right.
\end{abstract}

Keywords: Urban landscape. Legal asset. Quality of life. Human dignity. Fundamental right.

\footnotetext{
${ }^{1}$ Advogado. Pós-Graduando em Gestão Ambiental e Economia Sustentável (PUCRS). Especialista em Direito Ambiental (FMU). Bacharel em Direito pela Faculdade de Direito de Franca. Contato: rodrigo_hen@yahoo.com.br. http://lattes.cnpq.br/1543574670180463.
} 


\section{INTRODUÇÃO}

O meio ambiente artificial se encontra delimitado no espaço urbano construído, consistente no conjunto de edificações e assemelhados, albergando, ainda, ruas, praças e áreas verdes. Trata-se da construção, pelo ser humano, nos espaços naturais. É a transformação do meio ambiente natural em razão da ação antrópica. Trata-se, por fim, do local representado pelas cidades.

Um olhar rápido sobre as cidades brasileiras evidencia os resultados prejudiciais que o intenso (e muitas vezes desorganizado) processo de urbanização, decorrente do crescimento populacional verificado no país nas últimas décadas, trouxe à paisagem urbana, promovendo a construção de um modelo de cidade muitas vezes desapegado à valorização do aspecto estético, que é o oposto, muitas vezes, da proteção da paisagem urbana como indicador da qualidade de vida, vislumbrada no texto constitucional.

Paisagem urbana é aquela exposta, de forma compulsória, à coletividade, que pouco ou nenhum controle exerce sobre aquilo que lhe é dado ver e sentir nos espaços urbanos. É bem jurídico, relevante para a ordem jurídica, devendo ser destinatário de proteção legal.

A legislação brasileira contempla, de forma superficial, a paisagem urbana. Necessário é avançar sobre o assunto, vinculando a paisagem urbana ao direito à sadia qualidade de vida.

Esse tema ganha ainda mais relevância no sentido de que, de acordo com o último senso do IBGE, a população urbana representa mais de $80 \%$ do total. De acordo com esse órgão, entre 1970 e 2010, a população urbana passou de $55,9 \%$ para $84,4 \%{ }^{2}$.

Ademais, o direito a uma paisagem urbana mais ordenada, harmônica e equilibrada significa a supremacia do bem comum sobre qualquer outro interesse, seja particular ou corporativo, respeitando o espaço urbano, o patrimônio histórico-cultural, os espaços verdes e a integridade da arquitetura das edificações, alcançando-se, assim, o objetivo principal, que é o aumento da qualidade de vida e do bem estar da população urbana, além da proteção estética e salubre da paisagem.

\footnotetext{
${ }^{2}$ IBGE - Instituto Brasileiro de Geografia e Estatística. Atlas do censo demográfico. Disponível em: <http://censo2010.ibge.gov.br/apps/atlas/>. Acesso em: 14/02/2017. Ainda de acordo com os dados do IBGE (2010), percentual da população urbana na população total, por regiões: Centro-Oeste $(88,8 \%)$, Nordeste $(73,1 \%)$, Norte $(73,5 \%)$, Sudeste $(92,9 \%)$ e Sul $(84,9 \%)$.
} 
O cenário atual é de desequilíbrio, de desordem visual, provocada pelo acúmulo de objetos desconectados, como fios, faixas, antenas, postes, outdoors, anúncios de obras públicas, obras que não respeitam a arquitetura do local, entre muitos outros, o que resulta em um conjunto desarmônico, feio para os olhos, que degrada a paisagem urbana.

Existem políticas públicas visando o combate da poluição visual e seus reflexos, como a Lei Cidade Limpa do município de São Paulo, bem como outros regulamentos legais de outros municípios. Todavia, políticas públicas mais firmes, referentes à utilização do espaço visual urbano parecem ainda necessárias.

Esse trabalho estuda a paisagem urbana como bem jurídico e merecedora de proteção legal. Visa também associar a proteção da paisagem urbana ao conceito de qualidade de vida das populações nas cidades.

\section{O QUE É PAISAGEM URBANA?}

Tanto a doutrina quanto a legislação oferecem conceitos do que seja paisagem urbana. Para SILVA ${ }^{3}$, é a "roupagem com que as cidades se apresentam a seus habitantes e visitantes".

Já de acordo com GRANZIERA", a paisagem urbana "constitui o efeito visual das ruas, prédios, jardins e demais componentes das cidades, assim como sua integração".

O Decreto $n^{\circ}$. 15.364/1978 (revogado pelo Decreto $n^{\circ}$. 44.015/2003), do município de São Paulo, trazia, em seu art. $2^{\circ}$, a seguinte definição de paisagem urbana: "é a vista do conjunto das superfícies constituídas por edificações e logradouros da cidade".

$\mathrm{O}$ art. $2^{\circ}$, da Lei $\mathrm{n}^{\circ}$. 14.226/2006, a Lei Cidade Limpa, que ordena a paisagem no município de São Paulo, define paisagem urbana como sendo

O espaço aéreo e a superfície externa de qualquer elemento natural ou construído, tais como água, fauna, flora, construções, edifícios, anteparos, superfícies

\footnotetext{
${ }^{3}$ SILVA, José Afonso. da Direito urbanístico brasileiro, $4^{\text {a }}$ ed., revista e atualizada. São Paulo: Malheiros, 2006, p. 307.

${ }^{4}$ GRANZIERA, Maria Luiza Machado. Direito ambiental, $3^{\mathrm{a}}$ ed., revista e atualizada. São Paulo: Atlas, 2014, p. 669.
} 
aparentes de equipamentos de infra-estrutura, de segurança e de veículos automotores, anúncios de qualquer natureza, elementos de sinalização urbana, equipamentos de informação e comodidade pública e logradouros públicos, visíveis por qualquer observador situado em áreas de uso comum do povo.

A cidade de Recife editou a Lei $n^{\circ}$. 17.521/2008, que trata sobre a veiculação de anúncios e sobre o ordenamento da publicidade nesse município, aduzindo, no parágrafo $1^{\circ}$ do art. $2^{\circ}$, que paisagem urbana é

O espaço aéreo e a superfície externa de qualquer elemento natural ou construído, tais como, água, fauna, flora, construções, edifícios, anteparos, superfícies aparentes de equipamentos de infra-estrutura, de segurança e de veículos automotores, anúncios de qualquer natureza, elementos de sinalização urbana, equipamentos de informação e comodidade pública, a partir dos logradouros públicos visíveis por qualquer munícipe.

Paisagem é definida como a "extensão de território que se abrange num lance de vista; panorama, vista"5. Paisagem é, portanto, aquilo que, através da visão, se consegue assimilar, perceber. Dentre o que é perceptível, é possível distinguir o desenho, as formas, a silhueta que resulta desses objetos num determinado espaço. E, em verdade, é isso o que se vê, pois no campo visual de um observador que se lhe apresenta, não é possível isolar alguns objetos dos outros. Quem olha, vê o todo, o conjunto. Então, o conjunto das imagens visíveis, misturadas umas às outras é o que se apresenta ao observador. Isso é a paisagem.

\subsection{A PAISAGEM URBANA COMO BEM JURÍDICO}

Bem jurídico é todo aquele que possui utilidade, material ou não, valor econômico ou não, que é objeto de uma relação jurídica. De acordo com NÁUFEL ${ }^{6}$, é "tudo aquilo que pode ser objeto de direito".

\footnotetext{
${ }^{5}$ Grande dicionário larousse cultural da língua portuguesa. São Paulo: Nova Cultural, 1999, p. 683.

${ }^{6}$ NÁUFEL, José. Novo dicionário jurídico brasileiro, 8 a ed., volume I. São Paulo: Ícone Editora, 1988, p. 193.
} 
Sendo o bem tudo aquilo digno de tutela jurídica, inegável que o meio ambiente ecologicamente equilibrado, conforme disposto pelo caput do art. 225 da Constituição Federal, se enquadra nessa categoria; é bem jurídico. Como melhor ensina $\operatorname{SILVA}^{7}$, "o direito a que todos temos é à qualidade satisfatória, ao equilíbrio ecológico do meio ambiente. Essa qualidade é que se converteu em um bem jurídico".

Quando se fala em tutela jurídica do meio ambiente, a primeira ideia que surge é a de proteção dos recursos naturais. No entanto, a paisagem urbana, como parte integrante do meio ambiente, é bem jurídico, e, portanto, destinatária de proteção do direito, sendo tutelada pela Constituição Federal (arts. 23, 24, 30, 182, 216 e 225), Lei no . 10.257/2001 (Estatuto da Cidade), Lei $n^{\circ}$. 6.938/1981, Lei da Ação Civil Pública (Lei $n^{\circ}$. 7.347/1985, art. $1^{\circ}$, III), Lei $\mathrm{n}^{\circ} .4 .717 / 1965$ (art. $1^{\circ}$, parágrafo $1^{\circ}$ ), Lei ${ }^{\circ}$. 9.605/1998 (arts. 63 a 65), entre outros, de forma geral, e, de forma mais específica, pelas "Leis Cidade Limpa", como a Lei no. 14.223/2006 (Lei Cidade Limpa de São Paulo), Pernambuco (Lei n ${ }^{\circ}$. 17.521/2008), Londrina (Lei $n^{\circ}$. 10.966/2010), entre outros.

Pode-se dizer que a paisagem urbana é onde mais se identifica a presença do meio ambiente artificial. É nas cidades que a interação entre homem e habitat ocorre de forma mais plena.

FIORILLO relaciona a proteção jurídica da paisagem urbana com a ordem econômica estabelecida. De acordo com o autor,

A paisagem nas cidades (conjunto urbano paisagístico) absorve, evidentemente, não só aspectos vinculados ao meio ambiente natural (recursos naturais) mas, principalmente, todas as formas de expressão, bem como modos de viver dos diferentes grupos formadores de determinada sociedade abrangida por determinado espaço territorial. [...] A paisagem urbana, ao receber tutela jurídica, necessita considerar a defesa do meio ambiente cultural, artificial e natural no plano da ordem econômica capitalista, isto é, a paisagem urbana tem que ser observada no que se refere à aplicação da tutela jurídica ambiental dentro do contexto da sociedade contemporânea na qual vigora,

\footnotetext{
${ }^{7}$ SILVA, José Afonso. Direito ambiental constitucional, São Paulo: Malheiros, 2004, p. 83.
} 
como lembra Marilena Chaú, a ideologia pós-moderna $^{8}$.

No entanto, ainda que objeto de tutela jurídica, a legislação ainda se mostra tímida. Toma-se como exemplo, a Lei Cidade Limpa paulistana, que em seu art. $2^{\circ}$ define o que seja paisagem urbana. Reconhece-se, pela lei, uma dimensão da paisagem urbana como sendo bem de uso comum do povo, integrado ao patrimônio público portanto, cuja titularidade é de toda a coletividade, uma vez que se fala em sinais "visíveis por qualquer observador situado em áreas de uso comum do povo" (art. $2^{\circ}$, da Lei 14.223/2006). Ora, aqui, a lei deixa de reconhecer que também para aquele observador situado em área que não seja de uso comum do povo, a paisagem impõe-se, fazendo com que o observador a desfrute, mesmo sem o desejar.

\subsection{A COMPETÊNCIA MUNICIPAL PARA A TUTELA DA PAISAGEM URBANA}

A Constituição Federal de 1988 atribuiu ao Poder Público o dever de defesa e proteção do meio ambiente, conforme aduzido no art. 225 (“(...) impondo-se ao Poder Público e à coletividade o dever de defendê-lo e preservá-lo (...)" - grifos nossos). Ou seja, é obrigatório, uma vez que dever é "aquilo que se está obrigado pela lei, pela moral, pelos costumes, etc. $(\ldots)$.."

No que tange ao município, o art. 23 da Constituição Federal prevê à União, aos Estados, aos Municípios e ao Distrito Federal competência comum, pela qual tais entes integrantes da federação atuam em cooperação administrativa recíproca, visando alcançar os objetivos descritos pela própria Constituição.

Em relação ao meio ambiente, os incisos I e VI do citado artigo preveem que compete a esses entes: zelar pela guarda da Constituição, das leis e das instituições democráticas e conservar o patrimônio público e proteger o meio ambiente e combater a poluição em qualquer de suas formas.

\footnotetext{
${ }^{8}$ FIORILLO, Celso Antonio Pacheco. Curso de Direito Ambiental Brasileiro, $11^{\mathrm{a}}$ ed., revista, atualizada e ampliada. São Paulo: Saraiva, 2010, p. 327.

${ }^{9}$ Grande dicionário larousse cultural da lingual portuguesa. São Paulo: Editora Nova Cultural, 1999, p. 319.
} 
A Constituição Federal dispõe ainda, em seu art. 30, além, portanto da competência comum atribuída no art. 23, que compete aos municípios: legislar sobre assuntos de interesse local e promover a proteção do patrimônio histórico-cultural local, observada a legislação e a ação fiscalizadora federal e estadual.

Dispõe o art. 182 da Constituição Federal, que a política de desenvolvimento urbano deve ser executada pelo Poder Público municipal, buscando alcançar o ordenamento do pleno desenvolvimento das funções sociais da cidade e ainda garantir o bem-estar de seus habitantes.

Por fim, de acordo com REIS, os municípios, em relação ao meio ambiente, podem:

Legislar sobre a matéria ambiental; promover a educação ambiental; criar e organizar sua Secretaria Municipal de Meio Ambiente; criar e organizar o Conselho Municipal de Meio Ambiente; instituir e manter o Fundo Municipal de Meio Ambiente; integrar o Sistema Nacional do Meio Ambiente; exercer a fiscalização ambiental; realizar o licenciamento ambien$\operatorname{tal}^{10}$.

Cabe à cidade, portanto, dar atenção maior à questão da proteção da paisagem urbana, regulamentar e policiar (através de seu poder de polícia) a propaganda em meio aberto, pois tal atividade é nociva ao meio ambiente artificial, podendo, se não devidamente regulamentada e fiscalizada, provocar poluição visual, devendo observar, contudo, as normas editadas pelos Estados e União, de acordo com o art. 24 da Constituição Federal ${ }^{11}$.

\subsection{A PARTICIPAÇÃO POPULAR NA PROTEÇÃO DA PAISAGEM URBANA}

\footnotetext{
${ }^{10}$ REIS, Márlon Jacinto. O município e o meio ambiente. Apontamento sobre ação ambiental na órbita dos municípios. In Revista de Direito Ambiental nº. 35. São Paulo: Editora Revista dos Tribunais, julho-setembro, 2004, pp. 363/364.

11 “Art. 24. Compete à União, aos Estados e ao Distrito Federal legislar concorrentemente sobre: (...) VII - proteção ao patrimônio histórico, cultural, artístico, turístico e paisagístico;

VIII - responsabilidade por dano ao meio ambiente, ao consumidor, a bens e direitos de valor artístico, estético, histórico, turístico e paisagístico; (...)”.
} 
A sociedade é a destinatária final da proteção ambiental. Ademais, conforme o texto constitucional, também é seu dever, em conjunto com o Poder Público, a proteção e defesa do meio ambiente.

No entanto, ocorre, frequentemente, a sobreposição, com base no custo/benefício, de interesses econômicos (nacionais, regionais, etc.) em relação a interesses sociais de uma determinada população. Adota-se, para esta tomada de decisão, o princípio da supremacia do interesse público sobre o privado (ou sobre o menos público). E, muitas vezes, há o desrespeito a Direitos Fundamentais, tão relevantes quanto o desenvolvimento econômico do país.

Muitas vezes, a comunidade afetada não consegue se fazer ouvir, seja pela ausência de pessoal qualificado, seja pela falta de entendimento quanto aos seus direitos constitucionais e infraconstitucionais.

O exercício da cidadania não é concretizado no Brasil, principalmente quando se trata da participação na gestão ambiental. O desconhecimento quanto a ecologia, hidrologia, hidrogeologia, sociologia, economia, dentre outras ciências, predomina no "homem médio", grande massa de brasileiros. A mídia aliena, a escola não constrói cidadãos críticos e interesses não nobres corrompem comunidades com discursos pobres e sem base teórico-científica alguma.

No contexto urbano, entretanto, a população, melhor do que ninguém, tem condições de dizer o que lhe faz bem ou não, o que é esteticamente agradável na paisagem urbana, o que é funcional. São os habitantes da urbe capazes de dizer o que lhe ofende a vista, à integridade física, psíquica, o que lhe causa mal-estar. Como dito, ela é a destinatária da proteção ambiental.

Se à coletividade é previsto o dever de defender e preservar o meio ambiente, esta obrigação somente poderá ser exigida com a garantia da participação da sociedade como um todo. Para que a participação (que pode ser materializada através de consultas e audiências públicas, por exemplo) seja qualificada é imperioso garantir-se o direito à informação ambiental, para que haja, inclusive, a "conscientização pública" (art. 225, parágrafo $1^{\circ}$, VI, da Constituição Federal).

O art. $5^{\circ}$, XIV, da Constituição Federal de 1988, assegura a todos o acesso à informação. Ademais, são formas de participação popular, previstas na Carta Magna, em seu art. 14 e incisos: o voto direto e secreto, o plebiscito, o referendo e a iniciativa popular. 
No âmbito ambiental, a Política Nacional do Meio Ambiente (Lei $\mathrm{n}^{\circ}$. 6.938/1981) estabelece como um de seus objetivos a divulgação de dados e informações ambientais (art. $4^{\circ}$, inciso V), e, além disso, fixa como um dos instrumentos, previsto no art. $9^{\circ}$, XI, a garantia da prestação de informações relativas ao meio ambiente, ficando o Poder Público obrigado a produzir tais informações, quando inexistentes. A Declaração do Rio de Janeiro de 1992, também consagra o princípio em comento (Princípio 10 da Declaração):

A melhor maneira de tratar as questões ambientais é assegurar a participação, no nível apropriado, de todos os cidadãos interessados. No nível nacional, cada indivíduo terá acesso adequado às informações relativas ao meio ambiente de que disponham as autoridades públicas, inclusive informações acerca de materiais e atividades perigosas em suas comunidades, bem como a oportunidade de participar dos processos decisórios. Os Estados irão facilitar e estimular a conscientização e a participação popular, colocando as informações à disposição de todos. Será proporcionado o acesso efetivo a mecanismos judiciais e administrativos, inclusive no que se refere à compensação e reparação de danos ${ }^{12}$.

É fundamental o envolvimento da sociedade nas políticas ambientais urbanas, no que tange à proteção da paisagem urbana. Do contrário, o resultado de sua omissão é um prejuízo suportado por ela mesma,

Como entende FIORILLO, "porquanto o direito ao meio ambiente possui natureza difusa. Além disso, o fato de a administração desse bem ficar sob a custódia do Poder Público não elide o dever de o povo atuar na conservação e preservação do direito do qual é o titular"13.

\section{O DESEQUILÍBRIO DA PAISAGEM: A POLUIÇÃO VISUAL}

\footnotetext{
${ }^{12}$ ONU - Organização das Nações Unidas. Declaração do rio sobre meio ambiente e desenvolvimento. Disponível em: <http://www.onu.org.br/rio20/img/2012/01/rio92.pdf〉. Acesso em: 14/02/2017.

${ }^{13}$ FIORILLO, Celso Antonio Pacheco. Curso de Direito Ambiental Brasileiro, $11^{\text {a }}$ ed., revista, atualizada e ampliada. São Paulo: Saraiva, 2010, pp. 118/119.
} 
As alterações estéticas, tanto as positivas quanto as negativas, sobre o meio ambiente influenciam no bem-estar das pessoas e na qualidade de vida. Dessa forma, de acordo com MEIRELLES,

É fato incontroverso que a qualidade de vida dos moradores urbanos depende fundamentalmente dos recursos da Natureza, e muito em particular das terras, das águas e das florestas que circundam as grandes e as pequenas cidades, assim como das atividades exercidas em seus arredores ${ }^{14}$.

E a sadia qualidade de vida vincula-se, também, à paisagem urbana equilibrada. Havendo desequilíbrio, havendo uma agressão a esse bem jurídico, ocorre poluição, que é aquilo descrito na Lei nº ${ }^{\circ} 6.938 / 1981$, que em seu art. $3^{\circ}$. III, aduz:

Art. $3^{\circ}$ - Para os fins previstos nesta Lei, entende-se por: [...] III - poluição, a degradação da qualidade ambiental resultante de atividades que direta ou indiretamente: a) prejudiquem a saúde, a segurança e o bemestar da população; b) criem condições adversas às atividades sociais e econômicas; c) afetem desfavoravelmente a biota; d) afetem as condições estéticas ou sanitárias do meio ambiente; e) lancem matérias ou energia em desacordo com os padrões ambientais estabelecidos.

Poluição visual, por sua vez, é a "ultrapassagem do limite da visão para reconhecer as características naturais do meio, a partir da inserção de novas imagens ou deterioração da paisagem já existente" 15 .

De acordo com o autor, essas "novas imagens" podem ser caracterizadas pela construção de prédios ou monumentos em desacordo com as características estéticas da paisagem local. Podem ser ainda a colocação de placa, letreiros, material de publicidade, etc. por sua vez, a "deterioração da paisagem já existente" pode ocorrer pela degradação ou má conservação dos bens, sejam eles públicos ou particulares.

\footnotetext{
${ }^{14}$ MEIRELLES, Hely Lopes. Direito municipal brasileiro, $13^{\mathrm{a}}$ ed. São Paulo: Malheiros, 2003, pp. 494/495.

${ }^{15}$ MARQUES, José Roberto. Meio ambiente urbano, $2^{\mathrm{a}}$ ed. Rio de Janeiro: Forense Universitária, 2010, p. 156.
} 
A poluição visual também descaracteriza a urbe, "causando um sentimento de estranhamento", como ensina MARCHESAN, para, a seguir completar, dizendo que "o indivíduo não se reconhece mais na sua cidade, tamanha a sua descaracterização"

MARQUES também elenca as queimadas como contribuintes da poluição visual, uma vez que "os carvõezinhos (material particulado de maior tamanho) por elas produzidos se esparramam por toda a cidade, causando mal-estar à população" ${ }^{17}$ além, é claro, de contribuir para a poluição atmosférica.

Por fim, a jurisprudência já entendeu que o depósito irregular de lixo em zona urbana, além de outros efeitos negativos, caracteriza poluição visual $^{18}$.

Fato é que a poluição visual se encontra intimamente ligada ao meio ambiente artificial, onde pichações, placas, faixas, outdoors, construções em desacordo com o local, entre outros, são utilizados de forma muitas vezes exagerada ou indevida, degradando a paisagem urbana, prejudicando a qualidade de vida das pessoas.

A primeira preocupação com a poluição visual é a degradação estética da cidade. MEIRELLES lembra que

A estética urbana tem constituído perene preocupação dos povos civilizados e se acha integrada nos objetivos do moderno Urbanismo, que não visa apenas às obras utilitárias, mas cuida também dos aspectos artísticos, panorâmicos, paisagísticos, monumentais e históricos, de interesse cultural, recreativos e turístico da comunidade ${ }^{19}$.

No entanto, a preocupação não deve ser apenas estética. De acordo com MARCHESAN,

\footnotetext{
${ }^{16}$ MARCHESAN, Ana Maria Moreira. Mídia exterior e a paisagem abusiva: o respeito à paisagem urbana e ao patrimônio cultural. In Revista Magister de Direito Ambiental e Urbanístico no ${ }^{\circ}$ 61. Porto Alegre: Editora Magister, agosto/setembro, 2015, p. 116.

${ }^{17}$ MARQUES, José Roberto. Meio ambiente urbano, $2^{\mathrm{a}}$ ed. Rio de Janeiro: Forense Universitária, 2010, p. 161.

${ }^{18}$ TJSE, 2 a Câmara Cível. AI 2010216099/SE. Rel.: Desembargadora Marilza Maynard Salgado de Carvalho. DJ: 14.02.2011.

${ }^{19}$ MEIRELLES, Hely Lopes. Direito municipal brasileiro, 13a ed. São Paulo: Malheiros, 2003, pp. $543 / 544$.
} 
A preocupação com o tipo de vida das cidades é preponderante para definir o tipo de vida humana. Se a ela se quer imprimir a nota da qualidade, os cuidados com a paisagem são indispensáveis, não somente do ponto de vista estéticos, mas também da funcionali$\operatorname{dade}^{20}$.

A paisagem urbana (e as cidades) não basta apenas ser esteticamente aprazível. Deve ser funcional, ou seja, em suas formas, contornos, disposição no terreno, deve ser prático ou facilmente utilizável na função a que se destina.

É necessário haver um equilíbrio entre estético e funcional. Nesse sentido, SILVA ensina que "não se há de propugnar pelo esteticismo gratuito, mas se há de perseguir a integração do elemento estético como uma diretriz do desenvolvimento urbano" 21 . Afinal, a harmonia na paisagem urbana concorre para o equilíbrio e bem-estar (e consequentemente, para a qualidade de vida) dos habitantes da cidade.

Evitar a poluição visual significa limitar e restringir o modo de apresentação das construções (seja em suas formas, altura, disposição), tendo em vista uma composição harmoniosa da paisagem urbana, inclusive no que tange a preservação do meio natural da cidade. $O$ homem, muitas vezes, não aproveita o meio ambiente natural. Ao contrário, se aproveita dele, impermeabilizando o solo, desmatando, modificando o terreno, construindo em local proibido, enfim, gerando significativos impactos ao equilíbrio ambiental urbano, mutilando, muitas vezes, a paisagem ${ }^{22}$.

\footnotetext{
${ }^{20}$ MARCHESAN, Ana Maria Moreira. Tutela jurídica da paisagem no espaço urbano, 2008. Disponível em: <http://www.egov.ufsc.br/portal/sites/default/files/anexos/33269-42354-1-PB.pdf>. Acesso em: 14/02/2017.

${ }^{21}$ SILVA, José Afonso. Direito urbanístico brasileiro, $4^{\mathrm{a}}$ ed., revista e atualizada. São Paulo: Malheiros, 2006, p. 307.

${ }^{22}$ Nesse sentido: CONSTITUCIONAL. ADMINISTRATIVO. CONSTRUÇÃO DE PRÉDIO EM ZONA PROTEGIDA. EMBARGO. DENEGAÇÃO DE MANDADO DE SEGURANÇA. A competência para legislar a respeito de construção em área de preservação por força de existência de paisagens naturais notáveis, é simultânea da União, dos Estados, do Distrito Federal e dos Municípios, a teor do disposto nos arts. 23, III, e 24, VI e VII, da Constituição Federal. Precedentes jurisprudenciais. Improvimento do recurso. (STJ $-1^{\text {a }}$ Turma. RMS 9.279/PR. Rel.: Ministro Francisco Falcão. DJ: 07.12.1999).

O caso envolve a construção de prédio em área de preservação por força de paisagens naturais notáveis, de interesse turístico e paisagístico. Ocorreu a expedição de alvará de licença pelo Município sem a anuência prévia do Conselho de Desenvolvimento Territorial do Litoral Paranaense. Decidiu-se pela ilegalidade da licença e ausência de direito adquirido, por desrespeito aos arts. 23 e 24 da Constituição Federal.
} 
Evitar a poluição visual significa também a efetiva aplicação de normas legais que inibam o vandalismo nas construções, como pichações e depredações, bem como a efetiva aplicação das normas regulatórias de propagandas e placas de publicidade, que causa, muitas vezes, sensação de mal estar, além de prejudicar a visualização das características peculiares dos logradouros e das fachadas, com a perda de identidade do local.

A poluição visual, portanto, prejudica a qualidade de vida daqueles que habitam ou transitam pela cidade, mas não só; degrada o meio ambiente natural, compromete o meio ambiente cultural, depreciando bens de valor artístico ou histórico. Compromete também o turismo, repercutindo na economia local.

\section{A PAISAGEM URBANA COMO INDICADOR DE QUALIDADE DE VIDA}

Não há conceito legal do que seja qualidade de vida, mas, de acordo com MARQUES, trata-se de um conceito estático,

Enquanto sua aplicação ao homem, no dia a dia, é dinâmica, sofrendo influência direta do avanço científico. Assim, o que outrora se podia entender como condições satisfatórias hoje não se pode aceitar o mesmo título, porque a ciência possibilitou ao homem utilizar novos recursos que lhe proporcionassem melhores condições de vida ${ }^{23}$.

Nesse sentido, ensina LINHARES, que a qualidade de vida, "numa visão preliminar, pode ser vista como fenômeno tipicamente de mercado" 24 , mas "encontra-se associada ao bem estar das pessoas e à dignidade humana" 25 .

De acordo com DERANI, a qualidade de vida apresenta dupla natureza, que são concomitantes: a "do nível de vida material e do bem-

\footnotetext{
${ }^{23}$ MARQUES, José Roberto. Meio ambiente urbano, $2^{\mathrm{a}}$ ed. Rio de Janeiro: Forense Universitária, 2010, p. 34 .

${ }^{24}$ LINHARES, Paulo Afonso. Direitos Fundamentais e Qualidade de Vida. São Paulo: Iglu, 2002, p. 22.

${ }^{25}$ SOUZA, Demétrius Coelho. O meio ambiente das cidades. São Paulo: Atlas, 2010, p. 50.
} 
estar físico e espiritual. Uma sadia qualidade de vida abrange esta globalidade, acatando o fato de que um mínimo material é sempre necessário para deleite espiritual"26.

O conceito de qualidade de vida, certo é, difere de pessoa para pessoa, podendo ainda se alterar com o passar do tempo, associando-se à evolução industrial e tecnológica, sociocultural e econômica. Diversos fatores podem ser associados à qualidade de vida: saúde, educação, trabalho, lazer, saneamento básico, entre outros. Qualidade de vida é medida pela própria dignidade humana, valor protegido pelo art. $1^{\circ}$, III, e pelo art. 170, ambos da Constituição Federal, uma vez que pressupõe o atendimento das necessidades fundamentais da pessoa. O equilíbrio ambiental, é, no entanto, condição sine qua non para que os fatores acima citados possam ocorrer.

O direito a qualidade de vida se insere naqueles chamados de $d i$ reitos de $3^{a}$ geração, onde o direito ao meio ambiente ecologicamente equilibrado se faz presente, referido no art. 225 da Carta Magna como "essencial à sadia qualidade de vida”. Nesse sentido, ensina MILARÉ que

Um olhar sobre a paisagem urbana - fator condicionante da qualidade de vida das cidades, particularmente nos maiores centros e nas metrópoles - flagra um clima de calamidade e tensão decorrente das constantes agressões a que está sujeita. Umas são de natureza cultural (desrespeito ao que é público, desleixo e depredações); outras, de ordem comercial, alimentadas por anúncios insistentes de produtos e serviços ${ }^{27}$.

Como se percebe, a qualidade de vida é de suma importância para uma vida digna e sadia, sendo esse objetivo pretendido por diversos instrumentos, como o estudo de impacto de vizinhança (EIV), previsto no art. 37 , VII ${ }^{28}$, e do plano diretor, art. $39^{29}$, ambos previstos no Estatuto da Ci-

\footnotetext{
${ }^{26}$ DERANI, Cristiane. Direito ambiental econômico, $3^{\text {a }}$ ed. São Paulo: Saraiva, 2008, p. 59.

${ }^{27}$ MILARÉ, Édis. Direito do ambiente, $9^{a}$ ed., revista, atualizada e ampliada. São Paulo: Editora Revista dos Tribunais, 2014, p. 611.

${ }^{28}$ Art. 37. O EIV será executado de forma a contemplar os efeitos positivos e negativos do empreendimento ou atividade quanto à qualidade de vida da população residente na área e suas proximidades, incluindo a análise, no mínimo, das seguintes questões: (...) VII - paisagem urbana e patrimônio natural e cultural. (Grifos nossos).

${ }^{29}$ Art. 39. A propriedade urbana cumpre sua função social quando atende às exigências fundamentais de ordenação da cidade expressas no plano diretor, assegurando o atendimento das necessidades dos
} 
dade. Nesse sentido é o entendimento de FIORILLO, que aduz que "a política de desenvolvimento urbano tem uma finalidade maior que é a de proporcionar aos seus habitantes a sensação de bem-estar"30.

Viver no espaço urbano requer uma luta diária contra os mais diversos problemas que são criados pelo homem civilizado. Entre esses problemas, destaca-se o da poluição visual.

A paisagem urbana é obstruída por uma imensa quantidade de painéis e outdoors, faixas, pichações, letreiros, escondendo todo o espaço urbano, causado uma desordem que esconde todo um trabalho arquitetônico que um dia foi criado. A poluição visual causa não apenas prejuízos materiais, mas também indignação pelo desrespeito ao patrimônio alheio. A referência da cidade está na estética.

A saúde da população depende da qualidade ambiental. Quando ambiente está em desequilíbrio, há comprometimento na saúde das pessoas. Para se oferecer uma melhor qualidade de vida é necessário que se tenha controle sobre as atividades potencialmente poluidoras. Os problemas que a poluição visual causa a saúde humana são vários: estresse, nervosismo, violência.

As agressões ao meio ambiente suprimem a qualidade de vida das pessoas, interferindo em outros aspectos, além da saúde, bem-estar, qualidade de vida, ou padrões estéticos da paisagem. Interferem, inclusive, na economia, uma vez que passa a ser necessário corrigir os efeitos causados pela poluição.

Certo é que a paisagem urbana integrada, não degradada, equilibrada, harmônica e funcional concorre para a sadia qualidade de vida dos habitantes da urbe, essencial à saúde e ao bem-estar, alicerçado no princípio da dignidade humana e, portanto, verdadeiro direito fundamental. Do contrário, a poluição visual traz todo o tipo de ofensa à integridade das pessoas, habitantes ou não da urbe, violando o preceito de vida com qualidade.

\section{CONCLUSÕES ARTICULADAS}

cidadãos quanto à qualidade de vida, à justiça social e ao desenvolvimento das atividades econômicas, respeitadas as diretrizes previstas no art. $2^{\circ}$ desta Lei. (Grifos nossos).

${ }^{30}$ FIORILLO, Celso Antonio Pacheco. Curso de Direito Ambiental Brasileiro, $11^{\text {a }}$ ed., revista, atualizada e ampliada. São Paulo: Saraiva, 2010, p. 438. 
1. É notório que o meio ambiente possui status de bem jurídico. E dentre todos seus componentes, impossível ignorar a paisagem urbana, representada pelo conjunto de elementos que se apresentam ao observador, como detentora também desse status, digna de tutela jurídica. A proteção à paisagem urbana, por outra mão, ainda é insuficiente, apesar de diversas normas legais tutelarem esse bem. Necessário, então, a formulação de leis mais rígidas ou eficientes (e sua efetiva aplicação), visando harmonizar e equilibrar a paisagem urbana.

2. A poluição visual é a degradação ambiental resultante de publicidades ou propagandas, ou ainda, da má conservação de construções e, direta ou indiretamente, afeta a qualidade de vida, a saúde, a segurança e o bem-estar da população, bem como afeta as condições estéticas e funcionais do meio ambiente urbano, além de todo o potencial turístico da urbe.

3. Evitar a poluição visual significa limitar e restringir o modo de apresentação das construções (seja em suas formas, altura, disposição), tendo em vista uma composição harmoniosa da paisagem urbana, inclusive no que tange a preservação do meio natural da cidade. Significa também a efetiva aplicação de normas legais que inibam o vandalismo nas construções, bem como a efetiva aplicação das normas regulatórias das propagandas e placas de publicidade.

4. É preciso também que haja interesse popular na preservação da paisagem urbana, uma vez que, ainda que a paisagem urbana seja bem tutelado, a legislação não é cumprida e falta fiscalização. Afinal, de acordo com o texto constitucional, impõe-se, também à coletividade, o dever de defender e preservar o meio ambiente para as gerações presentes e futuras.

5. A sadia paisagem urbana está diretamente ligada à qualidade de vida da população, tratando-se da própria dignidade da pessoa humana, valor reconhecido pela Constituição Federal e que deve ser buscado para todos.

6. Finalmente, é dever de todos, sociedade e Poder Público, lutar contra o modelo de cidades que negligenciam o valor estético da paisagem urbana, valor intrínseco à paisagem, e as suas implicações na saúde psíquica e física do homem. 


\section{REFERÊNCIAS}

BERTRAND, Georges. Paisagem e geografia física global: esboço metodológico, 2004. Disponível em: <http://revistas.ufpr.br/raega/article/view/3389/2718>. Acesso em: 14/02/2017.

DERANI, Cristiane. Direito ambiental econômico, $3^{\text {a }}$ ed. São Paulo: Saraiva, 2008.

DINIZ, Maria Helena. Dicionário jurídico, vol. 1. São Paulo: Saraiva, 1988.

Grande dicionário larousse cultural da língua portuguesa. São Paulo: Nova Cultural, 1999.

FIORILLO, Celso Antonio Pacheco. Curso de Direito Ambiental Brasileiro, 11 ${ }^{\mathrm{a}}$ ed., revista, atualizada e ampliada. São Paulo: Saraiva, 2010.

GRANZIERA, Maria Luiza Machado. Direito ambiental, $3^{\mathrm{a}}$ ed., revista e atualizada. São Paulo: Atlas, 2014.

IBGE - Instituto Brasileiro de Geografia e Estatística. Atlas do censo demográfico. Disponível em: <http://censo2010.ibge.gov.br/apps/atlas/>. Acesso em: 14/02/2017.

LINHARES, Paulo Afonso. Direitos Fundamentais e Qualidade de Vida. São Paulo: Iglu, 2002.

MACHADO, Paulo Affonso Leme. Direito ambiental brasileiro. $18^{\circ}$ ed. revista, atualizada e ampliada. Direito ambiental brasileiro. São Paulo: Malheiros Editores, 2010.

MARCHESAN, Ana Maria Moreira. Mídia exterior e a paisagem abusiva: o respeito à paisagem urbana e ao patrimônio cultural. In Revista Magister de Direito Ambiental e Urbanístico nº 61 . Porto Alegre: Editora Magister, agosto/setembro, 2015, pp. 105/127.

. Tutela jurídica da paisagem no espaço urbano, 2008. Disponível em: 〈http://www.egov.ufsc.br/portal/sites/default/files/anexos/33269-42354-1-PB.pdf〉. Acesso em: $14 / 02 / 2017$.

MARCHESINI, Flávia de Sousa. Paisagem urbana e dano ambiental estético: as cidades feias que me desculpem, mas beleza é direito fundamental, 2009. Disponível em: <https://jus.com.br/artigos/21029/paisagem-urbana-e-dano-ambiental-estetico>. Acesso em: 14/02/2017.

MARQUES, José Roberto. Meio ambiente urbano, $2^{\mathrm{a}}$ ed. Rio de Janeiro: Forense Universitária, 2010.

MEIRELLES, Hely Lopes. Direito municipal brasileiro, 13 ${ }^{\mathrm{a}}$ ed. São Paulo: Malheiros, 2003.

MILARÉ, Édis. Direito do ambiente, $9^{a}$ ed., revista, atualizada e ampliada. São Paulo: Editora Revista dos Tribunais, 2014.

NÁUFEL, José. Novo dicionário jurídico brasileiro, 8ª ed., volume I. São Paulo: Ícone Editora, 1988.

ONU - Organização das Nações Unidas. Declaração do rio sobre meio ambiente e desenvolvimento. Disponível em: <http://www.onu.org.br/rio20/img/2012/01/rio92.pdf〉. Acesso em: 14/02/2017. Paisagem, natureza e direito, vol 1. Organizador Antonio Herman Benjamin. São Paulo: Instituto O Direito por um Planeta Verde, 2005. Disponível em: <http://www.planetaverde.org/arquivos/biblioteca/arquivo_20140211123726_2574.pdf>. Acesso em: 14/02/2017. 
RANGEL, Tauã Lima Verdan. Da ordenação da paisagem urbana, 2016. Disponível em: <http://www.conteudojuridico.com.br/artigo,da-ordenacao-da-paisagem-urbana,56726.html>. Acesso em: 14/02/2017.

REIS, Márlon Jacinto. O município e o meio ambiente. Apontamento sobre ação ambiental na órbita dos municípios. In Revista de Direito Ambiental nº. 35. São Paulo: Editora Revista dos Tribunais, julho-setembro, 2004, pp. 357/369.

SILVA, José Afonso. Direito ambiental constitucional, São Paulo: Malheiros, 2004.

Direito urbanístico brasileiro, $4^{\mathrm{a}}$ ed., revista e atualizada. São Paulo: Malheiros, 2006.

SOUZA, Demétrius Coelho. O meio ambiente das cidades. São Paulo: Atlas, 2010.

ZANOLLO NETO, Antonio. Direito à paisagem, 2010. Disponível em: <http://docplayer.com.br/6598949-Introducao-antonio-zanollo-neto-1.html>. Acesso em: 14/02/2017. 